\title{
Vegetable Charcoal and Pyroligneous Acid:Technological, Economical and Legal Aspects of its Production and Commerce
}

\author{
Doriana Daroit', Angela Beatrice Dewes Moura², Igor Paulo Domingues Martins ${ }^{3}$
}

\begin{abstract}
The production of vegetable charcoal generates atmospheric emissions, which can be controlled by the instalation of collectors for the condensation of such emissions, forming the pyroligneous acid. The development of collectors for the condensations and characterization of the acid for commerce can contribute with the local sustainable development. This study intends to investigate the technological, economical and legal aspects of the production and commerce of the pyroligneous acid. The chosen method was case study in Presidente Lucena/RS, Brazil, with use of surveys, interviews with producers and responsible government sectors' representatives. The results indicate that the pyroligneous acid extraction technique is little-known and little used by the producers, that the current market does not absorb the pyroligneous acid offering and the ruling is not relevant.
\end{abstract}

Keywords: local sustainable development; charcoal; pyroligneous acid; environmental innovation.

'Department of Administration - University of Brasília - Campus Darcy Ribeiro, ICC Ala Norte, Sala BI 5786, Asa Norte, Brasília, Brazil, Zip Code 70910-900. Phone +55 6I 3107-7107. E-mail: doriana.daroit@gmail.com

Feevale University - RS 239, N 2755, Novo Hamburgo, Rio grande do Sul, Brazil, Zip Code 93352-000. Phone +55 5I 5868800 R8936, E-mail: ${ }^{2}$ angelab@feevale.br, ${ }^{3}$ ipdmartins@gmail.com 


\section{Introduction}

For a long period of time, humanity and environment have been seen as separate and dichotomyc domains (Latour, 1997; Hopwood, Mellor, O'Brien, 2005). Human beings' way of survival bases itself in their ability to transform natural resources into products and services to supply their needs and satisfy their desires. The transformation of such natural resources requires a constant increase in the capacity to generate energy in order to meet the demand of productive processes. The technological development provided a number of energetic alternatives, some focused on nonrenewable resources, such as oil, others focused on renewable resources, such as hydroelectric, wind power and biomass resulted energy. According to IEA (20I2), it suits the government to play the leading role in the organization of stakeholders in order to generate investments in bioenergy through the development of policies, actions over markets and international cooperation.

One of the most ancient sources of biomass for obtaining energy is wood, which when partially burnt generates charcoal that possesses industrial and domestic use. The production of charcoal is a very important activity in some regions of Rio Grande do Sul/Brazil, not for generating return that will strongly affect the commercial trade of the State, but for being a significant activity for the generation of income for small agricultures.

This study is inserted in the search for the local sustainable development scenario. Development is a concept that has been faced in different ways through time and different societies. The economical development, as pointed out by Ray (1998), Giansanti (1998) and Souza (1995), is directed to the relationship between the growth of wealth, health, education, life expectancy and other benefits that might come from an increase of income. The concept of development might still be broadened and refer to the "process of expansion of real freedoms enjoyed by the people" (Sen, 2000, p. 17).

A more recently welcome perspective is the sustainable development (Comissão Mundial sobre Meio Ambiente e Desenvolvimento, 1988), that, besides economical aspects, considers the environmental and social elements as important guides for decisions and actions to be made. Sustainable development has been taking up space in international, national and local organizations (UN Millennium Development Goals, 2013,WDR, 2003) and it reflects concerns regarding the future of humanity (Hopwood, Mellor, O'Brien, 2005). According to Comissão Mundial sobre Meio Ambiente e Desenvolvimento (1988), some factors need to be harmonized so that a global sustainable development is actually achieved. Among such factors, we can highlight the meeting of basic needs; the democratization of population life improvement opportunities; a demographic harmony of the population through the adoption, by wealthier countries, of better consumer habits, like those of resources that are compatible with the environmental capacity; consonance of technological progress with the balance of vital ecosystems; and the search of viable alternatives in order to avoid the ending of non-renewable resources or the reach of their unsustainable point of use. Therefore, it is observed that sustainable development has a global dynamic that involves a relationship between countries and their manner of development. Santos (2005) discusses globalization by introducing it as a multifaceted phenomenon, i.e, depending on how you look at it, 'local' doesn't disappear by articulating itself in counter-hegemonic practices that can also be global.

To Sachs (2008), beyond economical, social and environmental dimensions, sustainable development also has two other dimensions: political, which refers to democratic governance, and territorial, which relates to the distribution of resources, populations and activities. Enrique Leff (2009) also points out the territoriality of development, placing, in the midst of the actions for sustainable development, the necessity for integration of ecosystems productivity, work processes and socially controlled technology, resulting in an endogenous development that will benefit local populations. In this scenario, we observe a double role of technology (here, understood in its broadest meaning, and not exclusively as product development): if, on one hand, its development was indeed the cause of many environmental problems, on the other, technology presents itself as a solution for the same environmental issues through the generation of environmental innovations. This means that the study and development of vegetable charcoal should be set as an important locus for articulating locally in order to reach global sustainable development, given that it is a traditional technology used by a number of populations in the Rio Grande do Sul/Brazil as a way of obtaining income for the landworking families.

Charcoal is created by a very rudimentary process of partially oven-burning wood, resulting in many byproducts. Pyroligneous extract is one of those byproducts and originated through pyrolysis. This process is subjected to variables related to temperature, raw materials and equipment (Campos, 2007). Production technology is very little efficient (38\% rate of maximum output), needing 7 to 10 kilos of wood for every I kilo of charcoal. The consumption of vegetable charcoal in the world is estimated in $\mathbf{4 0 . 5}$ million tons, being that Africa is responsible for the consumption of 19.5 million tons. Brazil is the main vegetable charcoal producer in the world, and it's destined mostly to the steel industry and domestic use (Greenpower, 2013), but also to the cement industry (IEA, 20I2). 
Brazil concentrates its production in South, Southeast and Northeast regions, featuring the state of Minas Gerais, where the majority of the production goes to the industry. From 1990 to 2006, the Brazilian provision reached a peak in 1997 of 3.783 thousand ton, a far superior number than the 1990 production of 1.838 thousand tons. The most current number refers to 2006, when 2.609 thousand tons were produced, indicating a decrease is compared to 1997, but still a constant increase since 2002 (Atlas Socioeconômico do Rio Grande do Sul, 2007).

The production of vegetable charcoal occurs in almost every area in the state of Rio Grande do Sul/Brazil, with great notice to the areas of Vale do Caí, Vale do Taquari and Baixo Jacuí. In these areas, counties such as Brochier, Paverama, Maratá, Butiá and Triunfo, among others, presented the largest amount of production (Atlas Socioeconômico do Rio Grande do Sul, 2007). Considering the data from 1990 to 2006 for that state, the year of 1995 presented the highest volume with 47.4 thousand tons, also very superior to 1997 production which had the smallest amount of 27.2 tons. Let it be noted that 1997 had the largest Brazilian production for that period. The most current number for Rio Grande do Sul is from 2006, with a provision of 41.3 thousand tons (Atlas Socioeconômico do Rio Grande do Sul, 2007).

Nascimento, Satler and Araújo (200I) affirm that some communities provide their sustenance with methods learnt throughout time, and that they could be 'untamed' methods, when it comes to the environment. However, this situation can be changed by a very well built/written project that could be applied to those communities. The involvement of local public government, in consonance with the projects from academic institutions, constitutes an important arrangement to the setting of initiatives that focus on the local sustainable development. The importance of this institutional arrangement and its actions reflect on one of the main negative environmental impacts resulting from the vegetable charcoal production: atmospheric emissions.

The release of atmospheric emissions, when it comes to charcoal, happen through combustion, a practice that is part of human initiatives to generate energy (Braga, et al., 2006). According to Comissão Mundial sobre Meio Ambiente e Desenvolvimento (1988) close to $70 \%$ of emerging countries' inhabitants consume dry wood for energy, with an average consumption of 700 kilos per year, provoking the scarcity of such resource. If wood burning is a common practice regarding the obtaining of energy by a great part of the population, than it's safe to say that "egetable charcoal is a more adequate and cleaner fuel than wood, and its smoke causes less respiratory disturbances and irritation to the eyes (Comissão Mundial sobre Meio Ambiente e Desenvolvimento, 1988).
Forestry grants raw materials for the production of vegetable charcoal, through the exploration of native forests and the planting of new homogenic forests with exotic species that promote better return. The use of native wood and varied species originates a charcoal with different degrees of quality, while the homogenic forest originates a better quality product and market price (Sablowski, 2008). Let it be noted that the use of forests planted in the 90's and 2000 has increased from 10\% to $72 \%$ (Calle, et al., 2005).

From the social-economical point of view, this market is characterized by employing a lot of people, but the activity in itself is historically connected to negative images relating to work conditions, deforestation, environment degradation e air pollution (Calle, et al., 2005; IEA, 20I2). However, with the implementation of planted woods, the related impacts are minimized because those woods are placed in poor lands, with little nutrients, considered inapt for agricultural practices and in regions of low demography. These characteristics of the planting areas may contribute with the movement of local economy, promoting its socioeconomical development (Calle, et al., 2005).

From the technological point of view, the productive process of vegetable charcoal presented little evolution due to a number of factors, among which we highlight the low degree of organization of the sector, which lacks investments, research and technical support from the government, academic institutions and the entrepreneurism field. Other factors such as decentralized geographic localization, focus on internal market, low level of technical knowledge and professionalization, and transportation in vehicles not specific for that purpose complement the lack of technological improvement of the process (Sablowski, 2008).

The partial burning of the wood that generates the charcoal consumes oxygen and releases carbon dioxide. This process happens through the use of ovens, since the most utilized ovens in Brazil, due to low investments and easiness in finding personal to built and manipulate them, are made of bricks or cement. This way, the technique is considered of low technology and innovation, also being connected to low investments, non qualified labor, and, in numerous cases, with inadequate working conditions (Sablowski, 2008).

The main point of the production of vegetable charcoal is based on the temperature control of the oven in which the wood is inserted, in a way to not go over the indicated levels to obtain a better quality product. The temperature inside the oven is manipulated through the controlled entry of air (oxygen), and the gases resulting of the combustion are usually expelled by chimneys. In this process, around $60 \%$ of the weight of the wood is lost through gas. The productive process can be divided in calorific phases, where each one rep- 
resents the levels of physical and chemical reactions that will impact on the quality of the finished product. Besides the temperature, other factor related to the wood will also impact in its quality such as form, dimension, humidity, density, homogeneity and chemical composition (Sablowski, 2008).

Still for Sablowski (2008), from the procedure above result, besides the vegetable charcoal as a final product, solid and gas residues. The gas ones may go through a process of condensation in order to originate pyroligneous acid or extract. The condensation can be achieved by the installation of collectors at the exits of the oven, which can be PVC tubes that direct the gas towards the exits promoting its cooling and consequent condensation throughout the length of the tube, dripping up to an opening slot at the basis of the tube. This liquid is composed of water, acetic and Formica acids, ether, acetone and tar, to name a few. The pyroligneous liquid can be used in organic and conventional cultures and the tar present in the compost may be used as fuel, as wood preservative and raw material for chemical and pharmaceutical industries. According to Campos (2007), the pyroligneous liquid may also be used in organic compost and composting, phytossanitary products, sterilizers, food additives and other agricultural utilization (Campos, 2007; Zulkarami, et al., 20 I I; Jung, 2007; Mansur, et al., 2013). It is important to highlight the necessity of distillation and dilution for certain uses.

From a legal perspective, the state of RS has expedited, through the Fundação Estadual de Proteção Ambiental FEPAM (State Foundation for Environmental Protection) a ruling, detailed through the Norma Técnica n. 002/1995 (Technical Standard) and approved by the Portaria Estadual 003/I 995 (State Legal Determination), both of which set the guidelines related to location and operation of the vegetable charcoal ovens. Such guidelines intend to define rules that in tune with the activity's nature and the quality of the air. Item 4 of the ruling states that the existing ovens and the ones that get installed should be located in rural areas, preferably along the site of production of wood and distant 500 meters at least from houses, interstate roads and railroads. The ovens must also be surrounded by a vegetable curtain, in order to provide better condition for the elevation of the gas emissions and its dispersion in the atmosphere. Item 5 predicts the 365-day deadline for the existing ovens to be adapted to the regulations. Item 6 sets penalties for violations to the Norma Técnica (Technical Standard), according to Law $6.437 / 1977$.

One obstacle for the commerce of vegetable charcoal is related to Resolution number $\mathbf{4 2 0}$ from the Agência Nacional de Transportes Terrestres (National Agency for Terrestrial Transportation), which classifies the product as dangerous and subjected to spontaneous combustion. However, according to Rohde (2005), this resolution is precipitated for scientific researches point to the improbability of spontaneous combustion of vegetable charcoal since the temperatures for that to occur must be quite above the ones reached in common environments.

When it comes to pyroligneous liquid, legislation is very generic situating it in either pesticide component or phytossanitary product for organic agriculture. Therefore, studies on its chemical characterization as well as its toxicity are urgent to provide orientation towards a specific legislation that does not harm its production and commerce.

Alas, the productive process of vegetable charcoal generates negative environmental impacts, such as atmospheric emissions. Part of those emissions can be condensed in order to create a byproduct of vegetable charcoal: the pyroligneous acid. This acid has considerable applicability in the chemical industry, especially regarding agriculture and food industry. However, its characteristics and uses are little studied. Besides, scarce knowledge of its composition and application makes it difficult to legally define it as well as to commercialize it. In accordance, this study aims to investigate technological, economical and legal aspects of the production and commerce of pyroligneous liquid.

\section{Method}

The research can be described as descriptive (Prodanov and Freitas, 2009; Marconi and Lakatos, 1999), utilizing the study case technique (Yin, 20I0). The Presidente Lucena County (RS/Brazil) was chosen as scenario for the study for being a site to traditional and significant in volume of charcoal production.

The collection of data happened through surveys presented to the charcoal producers in the county, in order to socially and economically characterizes the charcoal activity. Later, semi-structurally scripted interviews were conducted to investigate the experiences and know-how of those interviewed regarding vegetable charcoal and pyroligneous acid, their knowledge on legislation, information on the charcoal productive process, acid collection and information on its commerce.

\section{The respondents were:}

Respondent A - agriculture and environment policies Advisor from the Federação dos Trabalhadores na Agricultura FETAG - RS (Federation of Agriculture Workers);

Respondent $B$ - Chemical engineer and technician in charge of the environmental licensing department of FEPAM;

Respondent C - agronomy engineer and technician of EMATER/RS in charge of the Presidente Lucena county;

Respondent D - regional Director of Emater/RS; 
Respondent $\mathrm{E}$ - agronomy engineer and owner of Agronatura, company that uses pyroligneous acid as raw material for agricultural products;

Respondent F, G, H, I - vegetable charcoal producers form the Presidente Lucena county, selected by convenience.

The scripts for the interviews were different: for respondents $A$ to $E$, the questions focused on the legislation and commerce of charcoal and pyroligneous acid, while for the producers (respondents $\mathrm{F}$ to $\mathrm{I}$ ), the questions referred mainly to the productive process of charcoal and acid and their commerce. The interviews occurred mostly through the period of July to September of 2009, in the respondent's place of work, with the exception of proprietor of Agronatura (respondent $\mathrm{E}$ ) and the Emater technician (respondent $\mathrm{C}$ ), whose interviews took place at Expointer in the county Esteio/RS and the director of Emater (respondent D), whose interview was conducted through e-mail. The interviews were recorded and transcripted, being analyzed through the light of the theories thus presented, aiming to respond to the purpose of this study.

\section{Results}

\section{Socioeconomical characterization of the charcoal activity in Presidente Lucena}

As far as economical aspects of the charcoal activity goes, in Presidente Lucena there are 6 producers with 27 active ovens, I deactivated and none closed. Three of them produce and distribute charcoal and other 3 only produce, being that none of them only distributes. In each cycle of production (around 7 days) about $650 \mathrm{~kg}$ of charcoal per oven. All six rural properties some up to 69.9 hectares (ha), with average II.6ha per property. In total, there approximately $28 \mathrm{ha}$ of acacia-planted area and 3 ha of eucalyptus. There is a consumption of $347 \mathrm{~m} 3 / \mathrm{month}$ of wood. The average distance between the ovens and the site of collection of raw materials is $1.22 \mathrm{~km}$. Vegetable charcoal is sold in bags with average price of 0.64 reais (Brazilian currency). These data indicate that the charcoal industry is made by small producers which divide the use of their properties between charcoal and other agricultural and livestock activities.

As for the social aspects, the number of people working with vegetable charcoal, their gender, age and education were investigated. There are 19 people involved with the production of charcoal, of which 16 are men and 3 are women. Average age ranges from 18 to 65 years old. It was observed that two people are still school-aged.Another data obtained was the average time consumed by the production of charcoal which is $36.33 \%$, with the left over hours destined to agriculture, preparation of wood and studying.
When it comes to the environment, the total preservation area is of 10.5ha, with average of 1.75 ha per property. All charcoal properties produce coal fines, and most discard the residue on the plantation and some on the roads. Besides, all properties generate smoke (atmospheric emissions). The positive aspects refer to the inexistence of erosion and sound pollution on the properties as well as the presence of sanitary installations, electric energy and drinkable water. As to technology, the respondents indicated, as the main factors responsible for the quality of charcoal, the granulometric range, hardness and raw material. Only three producers use safety equipment and most use paper packing for the vegetable charcoal. The pyroligneous acid is not currently being produced by any producer.

Based on these data, it is possible to verify that, such as described in literature, the work conditions are precarious, creating environmental problems. The activity is a complement to other agricultural and livestock activities, being done by small rural producers that install the ovens on their farms.

\section{Productive process through producers' perspective}

The 04 respondents' years of professional experience with vegetable charcoal varied with broad difference: respondent I declared 02 years of experience while $\mathrm{G}$ has approximately 30 years. Through the observation of their workplace installations and the declarations in the interviews, it was verified that time of professional experience is not proportional to the structure of the ovens or of the adopted procedures for the production of charcoal which means that time of experience does not characterize a differential factor for the productive process when it comes to the added knowhow. Given that charcoal production technology remains virtually unaltered for many years, younger producers simply copy what they have learned from the older ones. The same discrepancy was observed regarding the number of ovens, since the longest active producer - respondent $\mathrm{G}$ - has only 2 ovens, while respondent $H$, with only 6 years of experience in the field works with 10 ovens.

The productive process may be considered rudimentary. In the words of respondent $F$, the operation of ovens and the consequent production of vegetable charcoal is this:

We have to place the piled wood inside the oven, and then a nest of blackened wood is made and subsequently placed in the fire. There are holes in the ovens where we jab a piece of wood, because if it gets through the wood in there, then it is already charcoal, and at that moment we have to close the holes (Respondent F). 
In picture I we verify how the producer uses a stake to measure the point of the charcoal. The stake must be introduced in the lateral hole of the oven so that the noise generated is heard, that is, if the wood makes a breaking sound, it means charcoal is ready. At this moment the hole is closed with pieces of brick and clay.

Another way of verifying the burning stage of charcoal is through the color of the smokes, for when it's bluish, it means charcoal is approaching ideal state, according to respondent $\mathrm{H}$. At that moment the holes in the oven are closed so that the fire is slowly extinguished. To reach burning stage, according to respondent $\mathrm{G}$, it takes 3 days, depending on the wind, and another 3 before removing the charcoal.

The ovens seen on the visited properties possess similar characteristics, being set apart by the amount of wood each one is capable of holding. Calle, et al. (2005) affirm that the most utilized ovens in Brazil are called "rabo-quente" (hottail), which are built of bricks, don't have chimneys, have 3 to 7 meters in diameter and 3.5 to 3.7 meters in height. These characteristics correspond to the ovens found on the respondents' properties.

It has been observed a difference in technology of the ovens. Respondent I closes the oven door when in cooling phase (after reaching charcoal burning stage and the subsequent bricking up of the holes in the structure of the ovens) with bricks and clay, having a support of wood firmly attached by a chain that surrounds the oven. This procedure differences itself from the one used by respondent $\mathrm{H}$, who has metal doors to close the ovens. When questioned on the reason for this method, respondent I said it is the most efficient, since it guarantees that oxygen will not get inside in cooling phase.

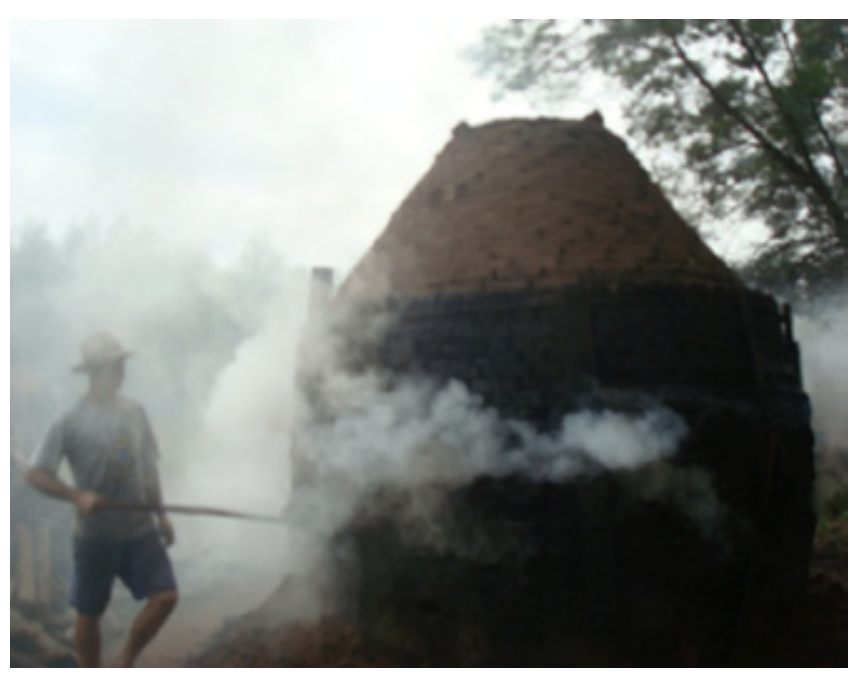

Figure I: Producer verifies the burning stage of charcoal.
After the cooling phase the door is opened and the charcoal, removed. It was possible to verify that some producers wear masks for this task, which represents a positive sign of protection against the dust created due to the removal of the product. Stating the existence of wood that has not reached ideal combustion level for charcoal, it can be reused in a new burning.

After its removal from the oven, the charcoal goes into a sieve. The bigger pieces are placed in bags for later packaging and weighing (paper packages of $4 \mathrm{~kg}$ ) while the smaller residues, according to the respondents, are destined to floricultures, food industries and agricultures to use as fertilize for the land. Due to the Expointer/2009, a producer presented a product originated from these smaller residues, which had been compacted into small spherical form, flattened in the poles, with around 5 centimeters in diameter. This method is described by Calle, et al. (2005) as briquetting. Some users of this product, passing through Expointer/2009, claimed their calorific characteristics to be as good as traditional charcoal. It is seen that the techniques employed by producers are simple and rudimentary in nature, which is in consonance to Sablowski (2008), which considers that the charcoal productive process has evolved very little over time, being defined by low technology and innovation, handcrafting labor and low investments, among other factors. Another characteristic described in literature and verified is the partial combustion of wood, for the process is interrupted at a certain point. Besides, the color of the smoke, as mentioned by respondent $\mathrm{H}$, is related as much to the burning stage of charcoal as the obtaining of pyroligneous liquid.According to Campos (2007), one of the ways of verifying the pyroligneous acid collecting stage I through the color of the smoke: yellow-gray smoke represents ideal stage, blue smoke represents high temperature inside the oven and, consequently, high concentration of tar, which affects the agricultural applicability of the acid.

Respondent $\mathrm{H}$ has a pyroligneous acid collecting system in some of ovens (the collecting system can be seen in figure 2). He highlighted the fact that the moment you collect the residue, the period of burning and cooling of the productive process goes from five to eight days, in average, i.e, there is a loss in productivity when the capitation of the acid occurs. In realizing that, there comes the need to increase the value of the residue commerce, since the producer when using the collect system ends up suffering damages when it comes to the productivity of their ovens, what leads to financial loss. Therefore, the technology of collection of pyroligneous liquid doesn't currently meet the production's financial needs, constituting an obstacle for its dissemination. Among the other interviewed producers, two had already seen the collecting system working in other locations, but they don't know pyroligneous acid neither its potential use. Alas, the

ISSN: 07 I8-2724. (http://www.jotmi.org)

Journal of Technology Management \& Innovation (c) Universidad Alberto Hurtado, Facultad de Economía y Negocios. 
technical know-how is not at all well distributed among the producers, and they themselves don't seem interested in collecting the pyroligneous acid, since they don't seek the means to implement it.

The one exception is interviewed $\mathrm{H}$ that has used the technique:

I produce in the back of the property, about 500 meters. I discovered a more effective way at the last installation I built, which works very well, with cheaper and more accessible costs and reduces the smoke in approximately $60 \%$ to $70 \%$. Thus, it works better in the way back, but you must be careful to be able to burn the coal, but after discovering it, the production flows. The problem is figuring out what to do with the acid (pyroligneous extract). It probably has 200 utilities, according to the Japanese, but it is still new here in the region, although some producers already know it and we already know its effect. It is not a poison to the land, it strengthens it. If you use it on the plants, you can even eat it without washing it, no problem. Here, in my family, we already considered it to be of medical use, since we used it on injuries to see the result. It is a burning substance, because if you use it pure on the plants they burn, but if you dilute it with water, it makes a process on the plant; however on the injury we use it pure. The product seems good, but until the people get to know it well, it will take some time and I'm afraid that my generation will not get to use it. I gave the product to my uncle, he produces grapes for own consumption, then he sprayed the grape with it and found that the product is very good (Respondent $\mathrm{H}$ ).

The applications described by the producer above are in tune to the ones mentioned in literature. However, for

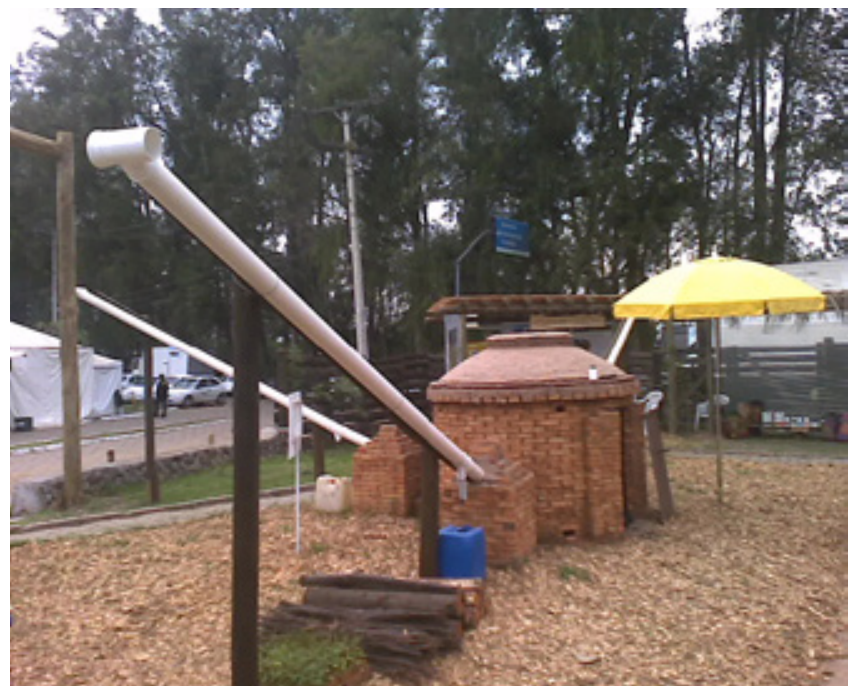

Picture 2: oven with pyroligneous acid collecting system exposed at Expointer/2009. being legally considered a pesticide its use is not really allowed. Thus, the need for a definition for pyroligneous acid is reinforced, in order to categorize it as non-risk pesticide, raw material or natural agent. Until present time, pyroligneous extract lacks definition regarding its properties or operational and application procedures. Therefore, scientific studies are need to better identify its chemical agents, with the purpose of setting a correct classification in the competent sectors.

Respondent $\mathrm{H}$, however, points out that his/her difficulty is related to the disposal of the residue, because the lack of knowledge of its applications prevents its sale in the equity market, even if the sale is made informally. Thus, respondent $\mathrm{H}$ does not use the collecting system at the moment, because it was disabled and so the ovens still produce coal releasing gases into the atmosphere. Otherwise, in every production cycle he/she could produce 300 to 500 liters of pyroligneous extract, equivalent to 40 or 50 liters per cubic meter of wood. The variability arises, according to the respondent, from humidity and age of the wood: the drier and older, the higher is the production.

Another point noted during the interviews concerns the Nota Técnica (Technical Standard) number 002/1995 cited above. In 2 of the 4 surveyed producers, it was found that there is a possibility of violation of the minimum distance of 500 meters of the ovens with respect to residential areas and roads, as well as the need for vegetable curtain around the ovens.

\section{Commerce of Pyroligneous Acid: experts' perspec- tive}

Respondents $A$ to $E$ are linked to government environmental agencies (FEPAM); research and dissemination of agricultural practices (Emater); farmers association (FETAG) and a private company (Agronatura). Their experiences with the production process of charcoal and pyroligneous liquid are quite varied: the members of Emater and Agronatura demonstrate much knowledge on the subject, while the representative of FEPAM demonstrates indirect involvement.

One interesting perspective was presented by respondent D, while reporting how he/she took notice of the pyroligneous extract:

For years Mr. Nagau, a farmer from Dois Irmãos, produced and disclosed the possibilities of using pyroligneous extract. He did not inspire a lot of credibility by total ignorance on our part, but also by what Nagau advocated, a veterinarian and medical use - including through ingestion - which we seemed far too exotic to us. Later, with the closer approach of some colleagues from Emater, we started some observa-

ISSN: 07 I8-2724. (http://www.jotmi.org) 
tions of the agricultural use to control pests in citrus plantations, in the municipality of Portão, in the Estrela region, with participation of a researcher from FEPAGRO (State Foundation for Agricultural Research). Only about 5 years ago, this involvement has become increasing, due to the demand from municipalities and also from the contacts with Feevale University and Embrapa because of other works (Respondent D).

Mr. Nagau, a farmer of Japanese origin, is indirectly cited by respondent $\mathrm{H}$ when he speaks on "200 utilities according to the Japanese" (Respondent $H$ ). Thus, the government experts had their attention directed to the applications of pyroligneous extract depending on the performance of the producers themselves.

Respondent $\mathrm{E}$ reports that his first contact with the extract occurred around the year 2000 in the town of Brochier/RS/ Brazil, where there was a furnace to capture the byproduct. Once there were more information regarding it, collecting tests in various ovens and studied composition and studies on the application and composition of the product were initiated. Subsequently, respondent E opened a company and transformed the extract into compost, that is, a natural fertilizer applied in various crops. The businessman points out that the most interesting aspect for the business is a raw material with the lowest possible concentration or absence of tar.

Respondent B demonstrates unfamiliarity with the details of the production chain of charcoal. Although working as a representative of the sector responsible for environmental licensing and monitoring, he/she states that his/her work does not get demands from this activity. This is due to the fact that there are few specific rules for the process of charcoal production and none for pyroligneous extract, which ends up being framed by general ruling or standard, as already discussed. Thus, the liquid is unknown by FEPAM.

In regard to the technology of pyroligneous fluid collection, the respondent $C$ has been accompanying the coal producers of Presidente Lucena for a year. According to him, in the first experiences accompanying a producer, a collection system that did not prove very effective was used in the ovens. However, through time another system was adapted, capturing from three furnaces next to each other, improving the process efficiency and even reducing the amount of smoke. With this increased efficiency resulting from the innovation in collecting pyroligneous fluid, there was generation of product stock, which ended up in the hands of the producer, because there was no allocation for it, given the few experiments to investigate its applications.

In this context, respondent $\mathrm{E}$ and his company can be seen as pioneers for the industrial application for pyroligneous extract, representing the possibility of a future market that can absorb, if not fully, at least partially the supply of pyroligneous fluid extracted, helping to solve the demand problem pointed out by the respondent $\mathrm{C}$. However, it is clear that the standardization of a system and collection procedure is required to guarantee the extraction of a product with a standardized and appropriate chemical composition for each consumer's market. In the case of respondent $E$, he highlights his interest for the residue with the lowest possible concentration of tar, a technique which can be manipulated as according to Campos (2007).

In regard to legal aspects, respondents $A$ and $C$ remind us that Instrução Normativa (Ruling Instruction) number 64 prohibits the use of pyroligneous extract in organic agriculture. Both respondents also point to the fact that the legislative reality little approaches pyroligneous acid, with considerable differences between state and federal references on gas emissions in general and on the use of pesticides and the likes of it. On the other hand, respondents B, D and $E$ have not demonstrated knowledge on specific legislation on the fluid, making only some considerations of general scope and one consideration of specific context regarding certain uses, which was the case of the respondent $E$.

On the subject of vegetable charcoal, respondents $A$ and $D$ made some considerations regarding the positioning of furnaces, which finds support in the Technical Standard number 002/1995. Respondents B, C, D and E did not make any references to the ruling that addresses the transport of charcoal and the origin and logging of wood to be used for this purpose. It can be seen that respondents $B$ and $E$ seem to ignore the state legislation intended for charcoal. The interviewee $B$ lets be known that his work and knowledge are restricted to certain technical issues for the record of activities that may have an environmental impact. However the Technical Standard 002/1995 was issued by FEPAM itself. He did stress, on the other hand, that producers can apply for an authorization for products undergoing experimental tests, which is characterized by having a limited time of validity which is defined by the requester, but that generally is valid for three months.

On the marketing of the extract, the respondent that showed some knowledge was $\mathrm{E}$, given that the subject refers directly to his activity. According to him, some states are exempting pyroligneous fluid from taxation, but he does not know the details on how this system works. He admitted to not knowing how the residue is traded, because all the raw material comes from a stock that he built himself through the studying and collecting of the residue during test phase about two years ago. The businessman expressed interest in knowing how to make the purchase and transportation

ISSN: 07 I8-2724. (http://www.jotmi.org)

Journal of Technology Management \& Innovation (c) Universidad Alberto Hurtado, Facultad de Economía y Negocios. 
of the product, a paramount for the company's expansion. Therefore, it is understood that the area surveyed does not have a formal trade on the fluid, but there is a need for an operating license in case of extraction and transportation of the product, as reported by the technician of FEPAM respondent $\mathrm{B}$.

Respondents were all deeply unaware of any fiscal or taxation practice linked to pyroligneous extract. The interviewee $D$ mentions that this practice is linked to the product classification. Thus, it is understood that the sources consulted do not know details on the procedure to be adopted, or else, there isn't a procedure to be adopted to date, i.e., the marketing of pyroligneous acid is attached to a number of technical regulatory and trade issues that still need to be met, which seems to explain the difficulty in finding an existing demand, as well as a ruling for it. In regard to the marketing difficulties, each of the interviewees mentioned problems aligned with their expertise:

The major difficulties are related to legislation (Respondent $A$ ).

The biggest difficulty is not bound to regular trade of the product, since the extract is an illustrious unknown, and does not have a regular consumption. What is missing are the technical data for the application of the product (Respondent $\mathrm{C}$ ).

I) Leaving a habitual procedure (traditional, historical), and of low cost, to a process which increases costs and procedures; 2) Not having accurate information; 3) Feeling alone, without assistance (technical, financial) to the necessary changes; 4) Being threatened, just to be working; 5) Not being prepared and organized ahead to the new environmental, legal demands (Respondent D).

The problem seems to be related to the market, because since it's a new product, it still faces a lot of resistance on the consumer's count. Farmers still have a lot of distrust in using the product (Respondent E).

And so the legal, technological and economic difficulties for the marketing of pyroligneous acid are identified.

\section{Discussion}

The production of charcoal in the municipality of Presidente Lucena/RS is made by families of small farmers who use it as a way to increase their income. Although the production of charcoal is tradicional and rudimentary, the collection of the fluid is recent and has technical, economic and legal issues that are interrelated. The technology for its collection was described by one of the producers interviewed as inefficient, requiring more time for the comple- tion of a production cycle of charcoal, although the technician from Emater has noted that changes in the collection system have made this technology more efficient. Thus, technological innovations are key to solve the economic problems arising from the activity. The resolution of these problems can turn the pyroligneous liquid byproduct in main product, given its higher added value granted by its possible applications. It is important to note that an efficient technology for the collection reduces atmospheric emissions (smoke) contributing to the reduction of negative environmental impacts.

The lack of characterization of the pyroligneous liquid is one of the factors that prevent its commercialization, since legislation cannot sort it properly. It is believed that the lack of market is a result of lack of knowledge of its properties and of the financial difficulties arising from their collection technology, and not a legislation related issue. In fact, the existing legislation is not known and it does not prevent the informal sale (albeit very little significant) of the product. Perhaps legislation is a factor that may be made relevant in the future in case there is a formal trade. Furthermore, the fact that it is a traditional technology hinders the uptake of innovations that could assist in establishing a market for the fluid.

In a socioeconomic system in which the energy demand expands continuously, the use and development of technologies that are geographically and culturally localized constitute the basis for sustainable local development, as advocated by Sachs (2008) and Leff (2009). In addition, the appreciation of local know-how coupled with the development of new technologies focused on improving the lifestyle of local populations may underlie its emancipatory process, and the exemplary nature of the technologies developed can lead their translation into other cognitive and spatial fields (Santos, 200I). This means exploring the possibilities of how the world can be, linking knowledge to their own context, comparing it with different contexts, and building a new relationship between the local and the global, between individuality and generality, underlining what Ernesto Laclau called 'the dignity of the specif', and determining the validity of its statements from the consequences of its involvement with the world (Nunes, 2005, p. 329).

The knowledge and the technologies derived from it are thus located and centered on choices about the world, i.e., they present ethical and political fundaments. For Jorgensen and Jorgensen (2009), simplistic technical solutions do not reduce or prevent environmental problems and may create new problems or divert attention from the need for integrated solutions to address the complexity of problems. The environmental innovation can be understood as the process of developing new ideas, behaviors, products and processes that can contribute to the reduction of environmental im- 
pacts or to achieve specific environmental objectives, requiring both technological and social changes (Hellström, 2007).

The interweaving between social, technological, economic, cultural, territorial and environmental factors and the uncertainties resulting from its complexity have been pointed out by many authors from various streams (Granovetter, 1985; Lundvall, et al., 2002; Nelson and Rosenberg, 1993; Latour , 2004; Leff, 2009) aimed for the generation of knowledge and the development of innovations. The creation and dissemination of innovations that contribute to sustainable local development passes not only by the "laws" of supply and demand, but also by the existence or creation of institutions (understood also as legitimate rulings or standards) to represent and act on the environmental complexity that involves actors with numerous interests, values and beliefs. Thus, it appears that an environmental innovation such as the collection of pyroligneous fluid, though it manages to reduce impacts on the environment - by reducing atmospheric emissions - it depends on other factors, notably economic and legal ones for its development and dissemination. With this, it is clear that an environmental innovation, as well as a strategy for sustainable development must meet the needs and characteristics of the local population so that their effective contribution to local sustainable development is achieved.

\section{References}

ATLAS SOCIOECONÔMICO DO RIO GRANDE DO SUL (2007). Atlas Socioeconômico do Rio Grande do Sul. www. scp.rs.gov.br/atlas/ [29.04.20I3].

BRAGA, B. et al. (2005). Introdução à Engenharia Ambiental. 2. ed. Pearson Prentice Hall, São Paulo.

CALLE, F. R. et al.(2005). Uso da Biomassa para Produção de Energia na Indústria Brasileira. Unicamp, Campinas.

CAMPOS, A. D. (2007). Técnicas para Produção de Extrato Pirolenhoso para Uso Agrícola. Circular Técnica 65. Embrapa Clima Temperado, Pelotas.

COMISSÃO MUNDIAL SOBRE MEIO AMBIENTE E DESENVOLVIMENTO (1988). Nosso Futuro Comum. Fundação Getúlio Vargas, Rio de Janeiro.

GIANSANTI, R. (1998). O Desafio do Desenvolvimento Sustentável. 6. ed.Atual, São Paulo.

GRANOVETTER, M. (1985). Economic Action and Social Structure: the Problem of Embeddedness. American Journal of Sociology, 9 I (3), 48I-5 I0.

GREENPOWER (2013). Statistics of charcoal production. Greenpower. http://www.piroliz.org/index.php/products/96statistics-of-charcoal-production.html [08.04.1013].

HELLSTRÖM,T. (2007). Dimensions of Environmentally Sustainable Innovation: the Structure of Eco-innovation Concepts. Sustainable Development, I5, I48-159.

IEA (20I2). Technology Roadmap: Bioenergy for Heat and Power. International Energy Agency. http://www.iea.org/ publications/freepublications/publication/bioenergy.pdf [29.04.2013].

JORGENSEN, M. S., Jorgensen, U. (2009). Green Technology Foresight of High Technology: a Social Shaping of Technology Approach to the Analysis of Hopes and Hypes. Technology Analysis \& Strategic Management. 2I (3), 363-379.

JUNG, K.H. (2007). Growth Inhibition Effect of Pyroligneous Acid on Pathogenic Fungus, Alternaria mali, the Agent of Alternaria Blotch of Apple. Biotechnology and Bioprocess Engineering, 12, 318-322.

LATOUR, B. (1997). Nous n'avons jamais été modernes. La Découverte, Paris.

LATOUR, B. (2004). Politiques de la nature. La Découverte, Paris.

ISSN: 07 I8-2724. (http://www.jotmi.org) 
LEFF, E. (2009). Ecologia, Capital e Cultura: a Territorialização da Racionalidade Ambiental.Vozes, Petrópolis.

LUNDVALL, B. Å., et al. (2002). National systems of production, innovation and competence building. Research Policy, 3I, 2|3-23|.

MANSUR, D., et al. (2013). Production of Ketones from Pyroligneous Acid of Woody Biomass Ppyrolysis over an Ironoxide Catalyst. Fuel, I03, I30-134.

MARCONI, M.A., Lakatos, E. M. (1999).Técnicas de Pesquisa: Planejamento e Execução de Pesquisas, Amostragens e Técnicas de Pesquisa, Elaboração,Análise e Interpretação de Dados. 4. ed.Atlas, São Paulo.

NASCIMENTO, L. F., Satler, M.,Araújo, M.A. (200I).A Caminho do Desenvolvimento Sustentável: O Caso de Três Municípios no Estado do Rio Grande do Sul. UFRGS, Porto Alegre.

NELSON, R, Rosenberg, N. (1993). National Innovation Systems: a Comparative Analysis. Oxford University Press, New York.

PRODANOV, C.C., Freitas, E.c. (2009). Metodologia do Trabalho Científico: Métodos e Técnicas da Pesquisa e do Ttrabalho Acadêmico. Feevale, Novo Hamburgo.

RAY, D. (1998). Development Economics. Princeton University Press, Princeton.

ROHDE, G.M. (2005). Evidências Científicas da Impossibilidade da Combustão Espontânea do Carvão Vegetal Produzido no Estado do Rio Grande do Sul. Série Técnica Especial. Cientec, Porto Alegre.

SABLOWSKI, A. R. M. (2008). Balanço de Materiais na Gestão Ambiental da Cadeia Produtiva do Carvão Vegetal para Produção de Ferro Gusa em Minas Gerais. (Doctoral Dissertation, Universidade de Brasília, 2008).

SANTOS, B. S. (2005). Os processos da globalização. In: Santos, B.S. (Org.) S. A globalização e as ciências sociais. $3^{\text {a }}$. ed. Cortez, São Paulo, pp. 25-102.

SEN, A K. (2000). Desenvolvimento como liberdade. Companhia das Letras, São paulo.

SOUZA, N.J. (1995). Desenvolvimento Econômico. 2. ed.Atlas, São Paulo.

UN MILLENNIUM DEVELOPMENT GOALS. United Nations Millenium Development Goals. www.un.org/millenniumgoals/ [29.04.20I3].
WDR (2003). Sustainable Development in a Dynamic World: Transforming Institutions, Growth, and Quality of Life. The Complete World Development Report Online. www. wdronline.worldbank.org [29.04.20I3].

YIN, R. K. (20I0). Estudo de Caso: Planejamento e Métodos. 4. Ed. Bookman, Porto Alegre.

ZULKARAMI, B., et al. (20I I). Effect of Pyroligneous Acid on Growth, Yield, an Quality Improvement of Rockmelon in Soilless Culture. Australian Journal of Crop Science, 5(12), I508-|5|4. 